\title{
FAKTOR RISIKO KEJADIAN DIABETES MELLITUS
}

(Risk Factors for The Event of Diabetes Mellitus)

\author{
Fitriani Nasution*, Andilala*, Ambali Azwar Siregar \\ *Sekolah Tinggi Kesehatan Indah Medan \\ Email: fitrianinasutionm.kes@gmail.com
}

\begin{abstract}
ABSTRAK
Pendahuluan: Penyakit Diabetes Mellitus merupakan ranking keenam penyebab kematian di Dunia. Di Indonesia Prevalensi DM sekitar 4.8\%. Faktor risiko terjadinya DM tipe II terdiri dari dua yaitu fakto yang tidak dapat dimodifikasi dan faktor yang dapat dimodifikasi. Berdasarkan survei yang dilakukan di wilayah kerja Puskesmas Tanjung Rejo masih ditemukan masyarakatnya mengalami kejadian diabetes mellitus. Tujuan dari penelitian ini adalah untuk megetahui faktor resiko terjadianya diabetes mellitus tipe 2 di wilayah kerja Puskesmas Tanjung Rejo. Metodologi: Jenis penelitian ini adalah penelitian observasional dengan rancangan studi case control. jumlah sampel secara keseluruhan 46 orang 23 kelompok kasus (penderita diabetes) dan 23 kelompok control (ukan penderita diabetes). Pengambilan data dengan menggunakan kuesioner dengan indikator usia responden, berat badan, tinggi badan, jenis kelamin, riwayat keluarga, riwayat hipertensi dan aktivitas fisik. Analisis data yang diguanakan adalah uji chi-square. Hasil:. Penelitian menunjukkan hasil bahwa faktor risiko diabetes mellitus tipe 2 adalah umur $(\mathrm{p}=0,032$, $\mathrm{OR}=5,6,95 \% \mathrm{CI}=1,038-30,204)$, riwayat keluarga $(\mathrm{p}=0,032, \mathrm{OR}=5,695 \% \mathrm{CI}=11,038$ $30,204)$ dan aktivitas fisik $(\mathrm{p}=0,003, \mathrm{OR}=7,3895 \% \mathrm{CI}=1,887-28,939)$ sedangkan jenis kelamin, riwayat hipertensi dan obesitas tidak berhubungan dengan kejadian Diabetes Melitus. Diskusi: Faktor yang paling dominan dalam mempengaruhi kejadiaan diabetes adalah aktivitas fisik, dimana seseorang yang kurang melakukan aktivitas fisik akan 5 kali lebih berisiko mengalami diabetes.
\end{abstract}

\section{Kata Kunci: Umur, Riwayat Keluarga, Aktivitas Fisik, Diabetes Mellitus}

\section{ABSTRACT}

Introduction: Diabetes Mellitus is the sixth cause of death in the world. In Indonesia, the prevalence of DM is around 4.8\%. The risk factors for type II diabetes mellitus consist of two, factors that cannot be modified and factors that can be modified. Based on a survey conducted in the working area of the Tanjung Rejo Public Health Center, the incidence/case of diabetes mellitus still found. The purpose of this study was to determine the risk factors for type 2 diabetes mellitus in the Tanjung Rejo Health Center work area. Methodology: This research was an observational study with a case control study design. The total sample size was 46 people, 23 cases (diabetics) and 23 control groups (diabetics). Retrieval of data using a questionnaire with indicators of the respondent's age, weight, height, gender, family history, history of hypertension and physical activity. The data analysis used was the chi-square test. Result $\therefore$ The study showed that the risk factors for type 2 diabetes mellitus were age ( $p=0.032, O R=5.6$, 95\% $C I=1.038-30.204)$, family history $(p=0.032$, OR $=5.695 \% C I=11.038-30,204)$ and physical activity $(p=0.003, O R=7.3895 \% C I=1.887-28.939)$ while gender, history of hypertension and obesity were not associated with the incidence of Diabetes Mellitus. Discussion: The most dominant factor in influencing the incidence of diabetes is physical activity, where someone who does not do physical activity is 5 times more likely to develop diabetes.

Keywords: Age, Family History, Physical Activity, Diabetes Mellitus 
ISSN Cetak 2303-1433

ISSN Online: 2579-7301

\section{PENDAHULUAN}

Diabetes merupakan penyakit tidak menular yang cukup serius dimana insulin tidak dapat diproduksi secara maksimal oleh pancreas (Safitri \& Nurhayati, 2019). Insulin merupakan hormone yang mengatur glukosa.Insulin yang tidak bekerja dengan adekuat akan membuat kadar glukosa dalam darah tinggi. Kadar glukosa darah normal adalah $70-110 \mathrm{mg} / \mathrm{dL}$ pada saat berpuasa (Fatimah, 2015). Diabates banyak dialami oleh masyarakat dan merupakan masalah kesehatan masyarakat yang global, sehingga pada saat ini mennjadi prioritas dalam memecahkan masalah kesehatan oleh para pemimpin dunia (Global, 2016).

\section{Penyakit Diabetes Mellitus} merupakan ranking keenam penyebab kematian di Dunia, hal ini diungkapkan oleh dunia World Health Organization (WHO) (Wicaksono, 2015). Data yang didapatkan bahwa kematian yang disebabkan karena diabetes ada sekitar 1,3 juta dan yang meninggal sebelum usia 70 tahun sebanyak 4 persen. Mayoritas kematian diabetes pada usia 45-54 tahun terjadi pada penduduk kota dibandingkan pada penduduk yang tinggal di pedesaan (Kistianita, Yunus, \& Gayatri, 2018). IDF memprediksikan DM akan menepati urutan ketujuh kematian dunia pada tahun 2030. Sejak Tahun 1980 terjadi peningkatan dua kali lipat penderita diabetes di dunia yatu dari $4,7 \%$ menjadi $8,5 \%$ pada populasi orang dewasa, hal ini juga merupakan indikator peningkatan obesitas pada beberapa dekade ini (Ogurtsova et al., 2017).

WHO juga menyebutkan bahwa sekitar 150 juta orang di dunia telah menderita diabetes mellitus (Saputri, Setiani, \& Dewanti, 2018). Penderita yang semakin meningkat jumlahnya setiap tahun sebagian besar berasal dari negara berkembang. Penduduk Amerika yang menderita diabetes sebanyak 29,1 juta jiwa dimana sebanyak 21 juta jiwa katagori diabetes yang terdiagnosis, sedangkan sebanyak 8,1 juta jiwa termasuk katagori diabetes tidak terdiagnosis (Andreas Pradipta et al., 2020).

Prevalensi diabetes di Indonesia menepati uruatan ketujuh tertinggi di dunia setelah China, India, USA, Brazil, Rusia dan
Mexico (Megawati, Agustini, \& Krismayanti, 2020). Berdasarkan data IDF tahun 2015 tentang penderita DM, penduduk Indonesia yang sudah mengalami penyakit ini sebanyak 10 juta orang (Group, 2015). Saat ini DM tipe II yang banyak terjadi tidak hanya pada orang dewasa saja tetapi pada usia anak dan remaja juga semakin meningkat (Fauziah \& Anggraeni, 2018).

Di Indonesia Prevalensi DM sekitar 4.8\% dan lebih dari setengah kasus DM (58.8\%) (Lathifah, 2017). DM tidak terdiagnosis. Diperkirakan sebanyak 21,3 juta masyarakat di Indonesia menyandang diabetes pada tahun 2030 (Prabowo \& Hastuti, 2015). Di Indonesia, diabetes juga masih menjadi persoalan kesehatan yang cukup serius bahkan terus mengalami peningkatan jumlah penderita di setiap tahunnya seiring bertambahnya jumlah penduduk, pertambahan usia, meningkatnya gaya hidup tidak sehat, pola makan tidak sehat, diet yang tidak sehat dan obesitas (Aryastami \& Tarigan, 2017).

Faktor risiko terjadinya DM tipe II terdiri dari dua yaitu faktor yang tidak dapat dimodifikasi dan faktor yang dapat dimodifikasi (Rovy, 2018). Faktor yang tidak dapat dimodifikasi adalah umur, jenis kelamin, dan faktor keturunan (Ujani, 2016). Faktor risko DM akan sering muncul setelah usia $\geq 45$ tahun. Sampai saat ini memang belum ada mekanismes yang jelas tentang kaitan jenis kelamin dengan DM, tetapi di Amerika Serikat banyak penderita DM berjenis kelamin perempuan. DM bukan penyakit yang dapat ditularkan, tetapi penyakit ini dapat diturunkan pada generasi berikutnya (Ramadhan, 2017). Seseorang yang keluarga kandungnya seperti orang tua maupun saudara kandung yang memiliki riwayat penderita DM akan berisiko lebih besar mengalami penyakit DM (Sukmaningsih, Heru SubarisKasjono, \& Werdani, 2016). Penelitian ini beda dengan yang lainnya karena menggunakan studi case control yang menghasilkan nilai odds ratio sehingga dapat digunakan dalam prediksi resiko kejadian diabetes.

Penelitian yang dilakukan di Talang Bakung Jambi menyatakan bahwa ada hubungan usia dan riwayat keluarga dengan 
ISSN Cetak 2303-1433

ISSN Online: 2579-7301

kejadian DM tipe II. pada Usia $\geq 45$ tahun lebih banyak pertama kali didiagnosis DM dibandingkan orang yang berusia $<45$ tahun. Hasil penelitin ini juga menyatakan bahwa seseorang yang memiliki riwayat keluarga DM akan mengalami resiko 4 kali lebih besar menderita DM tipe II (Rini \& Halim, 2018). Penelitian Kusnadi yang menyatakan seseorang dengan riwayat keluaraga DM akan berisiko 6 kali lebih besar dibandingkan dengan seseorang tanpa ada riwayat keluarga DM (Kusnadi, Murbawani, \& Fitranti, 2017).

Faktor resiko lain yang dapat dimodifikasi adalah faktor pola makan, kebiasaan merokok, obesitas, hipertensi, stress, aktifitas fisik, alcohol dan lain sebaginya. Adanya kaitan obesitas dengan kadar glokosa darah dimana IMT > 23 dapat menyebabkan peningkatan glukosa darah (Tandra, 2017).

$$
\text { Pergeseran zaman juga }
$$

memyebabkan pergeseran pola makan masyarakat, dimana pola makan masyarakat yang alami berubah menjadi modern. Sebagain besar pola makan modern banyak mengandung tinggi lemak, tinggi gula dan garam. Tidak hanya itu saja makanan cepat saji baik dalam bentuk kaleng maupun yang ditawarkan di berbagai outlet makanan juga semakin menjamur karena tingginya minat makan masyarakat dengan makanan cepat saji yang dapat meningkatkan kadar gula darah (VALOKA \& Reinaldi, 2017). Hasil penelitian dafriani yang dilakukan di Padang menyatakan bahwa ada hubungan anatara pola makan dengan kejadian diabetes mellitus (Dafriani, 2017).

Resiko lain penyebab kejadian diabetes mellitus adalah kurang aktivitas fisik. Gibney menyakatan bahwa aktivitas fisik yang rendah dapat berisiko peningkatan berat > $5 \mathrm{~kg}$ dan memilki resiko untuk mengidap diabetes mellitus (Breen, Ryan, Gibney, Corrigan, \& O'Shea, 2013). Penelitian yang dilakukan di Poliklinik Penyakit Dalam RSUD PadangPanjang menyatakan bahwa aktivitas fisik termasuk salah satu faktor resiko dengan kejadian dianetes mellitus (Dafriani, 2017).

Obesitas adalah faktor predisposisi diaman insulin mengalami resistensi, sehingga seseorang dengan obesitas ada resiko mengalami kejadian diabetes mellitus (Sudargo, Freitag, Kusmayanti, \& Rosiyani, 2018). Tidak hanya obesitas, penyakit tekanan darah tinggi juga dapat menyebabkan resistensi insulin, sehingga orang yang menderita hipertensimemiliki risiko menderita diabetes mellitus

Berdasarkan survei yang dilakukan di wilayah kerja Puskesmas Tanjung Rejo banyak ditemukan masyarakatnya mengalami kejadian diabetes mellitus tipe 2 dan dari penderita diabetes tersebut banyak yang mengalami koplikasi diabetes. Tidak hanya itu saja penderita DM di wilayah puskesmas ini juga setiap tahunnya mengalami kenaikan. Oleh karena itu perlu dilakukan penelitian faktor apa saja yang mempengaruhi kejadian DM agar resiko tersebut dapat dicegah. Tujuan dari penelitian ini adalah untuk megetahui faktor resiko terjadianya diabetes mellitus tipe $2 \mathrm{di}$ wilayah kerja Puskesmas Tanjung Rejo.

\section{BAHAN DAN METODE}

Jenis penelitian ini adalah penelitian observasional dengan rancangan studi kasus kontrol, yang dapat menilai hubungan paparan penyakit dengan cara menentukan kelompok kasus dan kelompok control. Populasi adalah seluruh pasien DM tipe 2 yang terdiagnosa yang berumur 40 tahun keatas sebanyak 23 orang sedangkan penentuan besar sampel ditetapkan dengan menggunakan rumus kasus kontrol perbandingan satu kasus dan satu control dimana jumlah sampel secara keseluruhan 46 orang 23 kelompok kasus dan 23 kelompok control (1:1).penelitian ini dilakukan pada bulan Desember 2019 di wilayah kerja Puskesmas Tanjung Rejo. Setiap responden bersedia menjadi sampel penelitian yang akan diminta untuk menandatangai surat pernyataan kesediaan menjadi responden dengan menggunakan materai. Variabel independent dalam penelitian ini adalah umur, jenis kelamin, riwayat keluarga, riwayat hipertensi, obesitas dan aktivitas fisik, sedangkan variable dependennya adalah kejadian diabetes mellitus tipe 2. Pengambilan data dengan menggunakan kuesioner. Analisis 
ISSN Cetak 2303-1433

ISSN Online: 2579-7301

data yang diguanakan adalah uji Chi-square. Etika penelitian anatara lain informed Consent(lembar persetujuan), anonimit dan confidentially.

\section{HASIL}

Karakteristik dari responden terdiri dari umur dan jenis kelamin, bisa di lihat pada tabel dibawah ini:

Tabel 1. Distribusi Frekuensi Berdasarkan Umur dan jenis kelamin Responden di Wilayah Kerja Puskesmas Tanjung Rejo

\begin{tabular}{lcrrr}
\hline & \multicolumn{3}{c}{ Kelompok Responden } \\
\hline & \multicolumn{2}{c}{ Kasus } & \multicolumn{2}{c}{ Kontrol } \\
\hline Kelompok & $\mathbf{n}$ & $\%$ & $\mathbf{n}$ & $\%$ \\
Umur & & & & \\
\hline$>45$ tahun & 21 & 91,3 & 15 & 65.2 \\
40-45 tahun & 2 & 8,7 & 8 & 34.8 \\
\hline
\end{tabular}

Jenis

Kelamin

\begin{tabular}{lrlll}
\hline Laki-laki & 8 & 34,8 & 6 & 26.1
\end{tabular}

$\begin{array}{lllll}\text { Perempuan } & 15 & 65,2 & 17 & 73.9\end{array}$

\begin{tabular}{lllll}
\hline Jumlah & 23 & 100.0 & 23 & 100.0 \\
\hline
\end{tabular}

Pada Tabel 1 berdasarkan umur mayoritas responden berusia $>45$ tahun sebanyak 21 orang $(91,3 \%)$ pada kelompok responden yang mengalami DM, sedangkan pada kelompok yang tidak mengalami DM sebanyak 15 orang $(65,3 \%)$. Jenis kelamin responden pada kedua kelompok mayoritas perempuan dimana pada kelompok kasus sebanyak 15 orang $(65,2 \%)$ dan pada kelompok kontrol sebanyak 17 orang (73,9\%).

Variabel riwayat keluarga, riwayat hipertensi, obesitas dan aktivitas fisik yang didapat melalui responden dapat dilihat sebagai berikut:
Tabel 2. Distribusi Frekuensi Berdasarkan Riwayat Keluarga, Riwayat Hipertensi, Obesitas dan Aktivitas Fisik Responden di Wilayah Kerja Puskesmas Tanjung Rejo

\begin{tabular}{|c|c|c|c|c|}
\hline \multirow[b]{3}{*}{$\begin{array}{l}\text { Riwayat } \\
\text { Keluarga }\end{array}$} & \multicolumn{4}{|c|}{ Kelompok Responden } \\
\hline & \multicolumn{2}{|c|}{ Kasus } & \multicolumn{2}{|c|}{ Kontrol } \\
\hline & n & $\%$ & $\mathbf{n}$ & $\%$ \\
\hline Ada & 8 & 34.8 & 2 & 8.7 \\
\hline Tidak ada & 15 & 65.2 & 21 & 91.3 \\
\hline $\begin{array}{l}\text { Riwayat } \\
\text { Hipertensi }\end{array}$ & & & & \\
\hline Ada & 4 & 17.4 & 2 & 8.7 \\
\hline Tidak ada & 19 & 82.6 & 21 & 91.3 \\
\hline Obesitas & & & & \\
\hline Obesitas & 10 & 43.5 & 8 & 34.8 \\
\hline $\begin{array}{l}\text { Tidak } \\
\text { Obesitas }\end{array}$ & 13 & 56.5 & 15 & 65.2 \\
\hline $\begin{array}{l}\text { Aktivitas } \\
\text { Fisik }\end{array}$ & & & & \\
\hline $\begin{array}{l}\text { Tidak } \\
\text { dilakukan }\end{array}$ & 19 & 82.6 & 9 & 39.1 \\
\hline Dilakukan & 4 & 17.4 & 14 & 60.9 \\
\hline Jumlah & 23 & 100.0 & 23 & 100.0 \\
\hline
\end{tabular}

Hasil didapatkan bahwa pada kelompok kasus dan kelompok control didapatkan hal yang serupa yaitu mayoritas responden tidak ada riwayat keluarga yang menderita DM, pada kelompok kasus sebanyak 15 orang $(65,2 \%)$ dan pada kelompok control sebanyak 21 orang $(91,3 \%)$. Pada riwayat hipertensi pada kelompok kasus lebih banyak ditemukan pernah mengalami hipertensi yaitu $17,4 \%$ dibandingkan kelompok control yang hanya $8,7 \%$. Pada variable obesitas pada kedua kelompok mayoritas responden tidak mengalami obesitas masing-masing sebanyak 13 orang $(56,5 \%)$ pada kelompok kasus dan sebanyak 15 orang $(65,2 \%)$. Pada aktivitas fisik mayoritas pada kelompok kasus tidak melakukan aktifitas fisik sebesar $82,6 \%$ dan pada kelompok kontrol mayoritas melakukan aktifitas fisik sebesar $60,9 \%$. 
ISSN Cetak 2303-1433

ISSN Online: 2579-7301

Tabel 3. Analisis Faktor Risiko DM (Umur, Jenis Kelamin, Riwayat Keluarga, Riwayat Hipertensi, Obesitas dan Aktivitas Fisik) dengan Kejadian Diabetes Mellitus di Wilayah Kerja Puskesmas Tanjung Rejo

\begin{tabular}{|c|c|c|c|c|c|c|c|}
\hline \multirow{3}{*}{ Variabel } & \multicolumn{4}{|c|}{ Kejadian Diabetes Mellitus } & \multirow{3}{*}{ p. } & \multirow{3}{*}{$O R$} & \multirow{3}{*}{$95 \% C I$} \\
\hline & \multicolumn{2}{|c|}{$\mathrm{Ya}$} & \multicolumn{2}{|c|}{ Tidak } & & & \\
\hline & $f$ & $\%$ & $f$ & $\%$ & & & \\
\hline \multicolumn{8}{|l|}{ Kelompok Umur } \\
\hline$>45$ tahun & 21 & 91,3 & 15 & 65.2 & 0,032 & 5,6 & $1,038-30,204$ \\
\hline 40-45 tahun & 2 & 8,7 & 8 & 34.8 & & & \\
\hline Total & 23 & 100.0 & 23 & 100.0 & & & \\
\hline \multicolumn{8}{|l|}{ Jenis Kelamin } \\
\hline Laki-laki & 8 & 34,8 & 6 & 26.1 & 0,522 & 1,51 & $0,426-5,359$ \\
\hline Perempuan & 15 & 65,2 & 17 & 73.9 & & & \\
\hline Total & 23 & 100.0 & 23 & 100.0 & & & \\
\hline \multicolumn{8}{|l|}{$\begin{array}{l}\text { Riwayat } \\
\text { Keluarga }\end{array}$} \\
\hline Ada & 8 & 34.8 & 2 & 8.7 & 0,032 & 5,6 & $1,038-30,204$ \\
\hline Tidak ada & 15 & 65.2 & 21 & 91.3 & & & \\
\hline Total & 23 & 100.0 & 23 & 100.0 & & & \\
\hline \multicolumn{8}{|l|}{$\begin{array}{l}\text { Riwayat } \\
\text { Hipertensi }\end{array}$} \\
\hline Ada & 4 & 17.4 & 2 & 8.7 & 0,381 & 2,21 & $0,363-13,470$ \\
\hline Tidak ada & 19 & 82.6 & 21 & 91.3 & & & \\
\hline Total & 23 & 100.0 & 23 & 100.0 & & & \\
\hline \multicolumn{8}{|l|}{ Obesitas } \\
\hline Obesitas & 10 & 43.5 & 8 & 34.8 & 0,546 & 1,44 & $0,439-4,741$ \\
\hline Tidak Obesitas & 13 & 56.5 & 15 & 65.2 & & & \\
\hline Total & 23 & 100.0 & 23 & 100.0 & & & \\
\hline \multicolumn{8}{|l|}{ Aktivitas Fisik } \\
\hline Tidak dilakukan & 19 & 82.6 & 9 & 39.1 & 0,003 & 7,38 & $1,887-28,939$ \\
\hline Dilakukan & 4 & 17.4 & 14 & 60.9 & & & \\
\hline Total & 23 & 100.0 & 23 & 100.0 & & & \\
\hline
\end{tabular}

Hasil uji statistik menyatakan bahwa yang menjadi faktor resiko kejadian diabetes mellitus di wilayah kerja Puskesmas Tanjung Rejo anatara lain umur, riwayat keluarga dan aktivitas fisik, sedangkan jenis kelamin, riwayat hipertensi bukan faktor yang berhubungan. Faktor umur secara signifikan $\mathrm{p}=0,032<0,005$ dengan $\mathrm{OR}=5,6$ menyatakan bahwa penderita DM tipe 2 kemungkinan berusia $>45$ tahun 5,6 kali lebih besar dibandingkan dengan kelompok kontrol ( $\mathrm{p}<0,05$ ). Faktor riwayat keluarga secara signifikan $\mathrm{p}=0,032<0,005$ dengan $\mathrm{OR}=5,6$ menyatakan bahwa penderita DM tipe 2 kemungkinan memiliki riwayat keluarga penderita DM 5,6 kali lebih besar dibandingkan dengan kelompok kontrol ( $\mathrm{p}$ $<0,05)$. Faktor secara signifikan $\mathrm{p}=0,003$ $<0,005$ dengan $\mathrm{OR}=7,3$ menyatakan bahwa penderita DM tipe 2 kemungkinan berusia tidak melakukan aktivitas fisik 7,3 kali lebih besar dibandingkan dengan kelompok kontrol $(\mathrm{p}<0,05)$.

\section{PEMBAHASAN}

Hasil penelitian faktor usia memiliki hubungan dengan kejadian diabetes mellitus di Wilayah Kerja Puskesmas Tanjung Rejo. Secara teoritis faktor risiko initidak dapat dirubah karena semakin tua umur maka searah dengan proses metabolisme tubuh dimana kerja organ tubuh mulai berkurang seiring dengan pertambahan umur, apalagi jika tidak pernah melakukan olahraga secara teratur (Dewi \& Gz, 2014). Hal ini juga terjadi pada proses metabolisme glukosa dalam tubuh.

Penelitian Kurniaty yang dilakukan di Lampung juga menyatakan hal yang sama bahwa usia tua lebih berisiko mengalami DM dibandingkan usia muda (Kurniawaty \& Yanita, 2016), Penelitian yang dilakukan 
ISSN Cetak 2303-1433

ISSN Online: 2579-7301

oleh Palimbungan menyatakan odds rasio umur didapatkan nilai 5,86, hasil yang didapatkan hamper sama dengan penelitian ini dnegan odss ratio 5,6 (Palimbunga, Ratag, \& Kaunang, 2017).

Laporan riset kesehatan dasar 2013 juga mengemukakan bahwa penderita diabetes paling banyak berada pada kelompok umur 45 tahun-54 tahun (Kementerian Kesehatan, 2013). Tidak hanya berdasarkan laporan riset kesehatan dasar, perkumpulan Endokrinologi juga menyatakan umur $>45$ tahun salah satu factor pencetus terjadi DM. Penelitian yang dilakukan di Negeria menyatakan bahwa resiko mengalami DM tipe II lebih condong meningkat semenjak memasuki usia 46 tahun (Ekpenyong, Akpan, Ibu, \& Nyebuk, 2012).

Hasil penelitian di RSUP Prof Kandou Manado yang dilakukan oleh kakanusa menyatakakan bahwa faktor resiko usia memiliki nilai odds ratio 7,6 sehingga resiko usia $>45$ tahun delapan kali kali lebih besar dibandingkan dengan usia dibawahnya (Kekenusa, Ratag, \& Wuwungan, 2013).

Hasil penelitian juga menunjukkan bahwasanya ada beberapa responden yang berusia kurang dari 45 tahun juga mengalami kejadian DM. Hal ini juga menunjukkan bahwa memang tidak hanya dari faktor umur saja tetapi ada faktor-faktor lain yang dapat menyebabkan kejadian DM. Tetapi secara statistic dalam penelitian ini menjunkkan bahwa seamkin tua usia seseorang maka prevalensi mengalami diabetes semakin tinggi juga.

Penelitian ini menjelaskan bahwa riwayat keluarga merupakan salah satu faktor resiko kejadian DM tipe II, seseorang dengan riwayat keluarga DM akan lebih besar beriko mengalami DM dibandingkan yang tidak memiliki riwayat keluarga DM. DM merupakan salah satu tipe penyakit dengan garis keturunan. Hal ini sesuai bahwa risiko seorang anak, jika salah satu orang tuanya DM sebesar $15 \%$ dan resikonya sebesar $75 \%$ jika kedua orang tuanya mengalami DM (Trisnawati \& Setyorogo, 2013).
Rohmi pada survei risiko penyakit DM menyatakan bahwa riwayat keluarga merupakan faktor resiko DM pada masyarakat Padang, sehingga masayrakat dengan riwayat DM keluarga berpeluang lebih besar mengalami DM (Yosmar, Almasdy, \& Rahma, 2018). Penelitian di masyarakat Padang juga menunjukkna hal yang sama dengan penelitian yang dilakukan di Percut Sei Tuan bahwa riwayat keluarga merupakan factor resiko dari DM. Hasil didapatkan odds ratio sebesar 4,7 dimana seseorang dengan riwayat keluarga DM akan lima kali lebih beresiko mngalami DM.

Hasil penelitian Imelda di Puskesmas Harapan Raya faktor yang paling mempengaruhi terjadinya diabetes Miliatus antara lain riwayat keturunan, pola makna yang tidak sehat dan aktifvitas fisik yang kurang (Imelda, 2019). Faktor Risiko Kejadian DM Di Puskesmas Kecamatan Cengkareng dengan analisis uji fisher exact antara lain riwayat keluarga usia, stress, kadar kolesteol, tekanan darah dan aktivitas fisik (Trisnawati \& Setyorogo, 2013). Penelitian lainnya menyebutkan bahwa riwayat keluarga memiliki nilai odds ratio 7,875 sehingga faktor resiko dari riwayat keluarga dengan DM lebih tinggi 8 kali dibandingkan yang tidak.

Hasil penelitian ini memang tidak semua responden yang memiliki riwayat keluarga DM tidak mengalami DM, hal ini dapat diasumsikan karena pola makan yang sehat ataupun karena melakukan aktvitas fisik yang cukup. Olah karena itu, faktor resiko yang tidak dapat diubah seperti umur dan riwayat keluarga dapat diminimalisir dengan pola hidup sehat.

Aktivitas fisik merupakan salah satu cara dalam menurunkan kadar gula darah (Herwanto, Lintong, \& Rumampuk, 2016). Pada saat melakukan aktivitas fisik seperti olahraga, otot menggunakan glukosa yang tersimpan untuk diubah menjadi energy, jika penyimpanan tersebut kosong maka yang akan digunakan adalah glukosa dalam darah sehingga glukosa darah turun akan menurun.

Hasil penelitian menunjukkan bahwa aktivitas fisik merupakan faktor resiko kejadian DM di Puskesmas Percut Sei Tuan dengan nilai signifikasi $\mathrm{p}<0,005$. 
ISSN Cetak 2303-1433

ISSN Online: 2579-7301

Artinya bahwa responden yang tidak malakukan aktivitas fisik yang cukup akan memperbesar resiko mengalami kejadian DM. Berdasarkan informasi responden yang jarang melakukan olahraga dan mengalami kejadian DM, mengatakan sangat malas melakukan olahraga kebiasaan mereka dulu memilih santai duduk, menonton TV sambil mengemil menyebabkan penimbunan lemak dan gula dalam tubuh.

Hasil penelitian ini sesuai dengan penelitian yang dilakukan Sari, faktor resiko seseorang yang tidak melakukan aktivitas fisik yang cukup lebih besar sebelas kali lebih besar dibandingkan dengan seseorang yang melakukan aktivitas yang cukup dengan nilai signifikasi 0,009 (Purnama \& Sari, 2019).

Pada era yang sangat canggih ini semua jenis pekerjaan dapat dibantu oleh berbagai mesin mulai dari pekerjaan rumah tangga hingga pekerjaan kantoran semua dibantu oleh mesin, sehingga pergerakan tubuh menjadi sangat minimal, oleh karena itu saat ini sangatlah penting untuk melakukan olahraga yang teratur seperti jalan kaki, berenang, bersepeda, maupun senam. Olah raga teratur akan meningkatkan metabolisme tubuh sehingga dapat tetap menjaga berat badan tubuh, Keteraturan dalam melakukan olehraga akan meningkatkan metobolisme tubuh termasuk meningkatkan produksi insulin (Lathifah, 2017).

Aktivitas Fisik memanglah sangat penting, saat ini banyak masyarakat awan yang belum peduli dengan kegiatan olahraga. Kegiatan Olahraga banyak digandrungi masyarakat kelas sosial atas yang menunjukkan style hidup seperti olahraga senam aerobic, basket, golf, berenag dan lain sebagainya oleh karena itu, masyarakat perlu di edukasi bahwa melakukan aktivitas fisik tidak perlu mahal seperti berjalan kaki, senam dengan melihat youtube yang bisa dipraktekkan di rumah tanpa harus membayar instruktur dan berlari.

\section{SIMPULAN DAN SARAN Simpulan}

Penelitian yang dilakukan di wilayah kerja Puskesmas Tanjung Rejo Percut Sei
Tuan tentang resiko kejadian Diabetes Melitus tipe 2 didapatkan hasil ada hubungan umur, riwayat keluarga dengan kejadian Diabetes Melitus sedangkan jenis kelamin, riwayat hipertensi dan obesitas tidak memiliki hubungan dengan kejadian Diabetes Melitus

\section{Saran}

Diharapkan kepada tenaga kesehatan dapat melakukan promosi kesehatan tentang penyakit Diabetes Melitus dan menjelaskan faktor-faktor resiko dari penyakit tersebut. Bagi masyarakat untuk dapat selalu rutin melakukan pengevekan gula darah terkhusunya pada usia > 45 tahun dan juga yang memiliki riwayat keluarga penderita DM. Selalu melakukan olahraga rutin minimal 3 sampai 4 kali seminggu agar tubuh tetap sehat dan metabolisme tubuh berjalan dengan baik.

\section{KEPUSTAKAAN}

Andreas Pradipta, A. P., Anggi Widiaswati, A. W., Cornelia Indah Y, C. I. Y., Friska Apriliyanti, F. A., Lakukua, M. F., Lakukua, M. F., ... Ruth Maya S, R. M. S. (2020). EFEK OLIVE OIL TOPICAL TERHADAP PERAWATAN LUKA DIABETES MELITUS. DISS, Universitas Kusuma Husada Surakarta.

Aryastami, N. K., \& Tarigan, I. (2017). Kajian kebijakan dan penanggulangan masalah gizi stunting di Indonesia. Buletin Penelitian Kesehatan, 45(4), 233-240. JOUR.

Breen, C., Ryan, M., Gibney, M. J., Corrigan, M., \& O'Shea, D. (2013). Glycemic, insulinemic, and appetite responses of patients with type 2 diabetes to commonly consumed breads. The Diabetes Educator, 39(3), 376-386. JOUR.

Dafriani, P. (2017). Hubungan Pola Makan dan Aktifitas Fisik Terhadap Kejadian Diabetes Melitus di Poliklinik Penyakit Dalam RSUD dr. Rasidin Padang. NERS Jurnal Keperawatan, 13(2), 7077. JOUR.

Dewi, R. K., \& Gz, S. (2014). Diabetes bukan untuk ditakuti. BOOK, FMedia. Ekpenyong, C. E., Akpan, U. P., Ibu, J. O., 
ISSN Cetak 2303-1433

ISSN Online: 2579-7301

\& Nyebuk, D. E. (2012). Gender and age specific prevalence and associated risk factors of type 2 diabetes mellitus in Uyo metropolis, South Eastern Nigeria. Diabetologia Croatica, 41(1). JOUR.

Fatimah, R. N. (2015). Diabetes melitus tipe 2. Jurnal Majority, 4(5). JOUR.

Fauziah, I., \& Anggraeni, D. N. (2018). Prevelensi Penderita Diabetes Melitus Tipe II pada Pasien di Puskesmas Kota Blangkejeren, Kecamatan Blangkejeren, Kabupaten Gayo Lues Tahun 2015-2017. JOUR.

Global, T. B. (2016). Report 2016. Methods Used by WHO to Estimate the Global Burden of TB Disease, Glaziou P., Sismanidis C., Zignol M., Floyd K., Global TB Programme, WHO, Geneva, Switzerland. JOUR.

Group, I. D. F. D. A. (2015). Update of mortality attributable to diabetes for the IDF Diabetes Atlas: Estimates for the year 2013. Diabetes Research and Clinical Practice, 109(3), 461-465. JOUR.

Herwanto, M. E., Lintong, F., \& Rumampuk, J. F. (2016). Pengaruh aktivitas fisik terhadap kadar gula darah pada pria dewasa. EBiomedik, 4(1). JOUR.

Imelda, S. I. (2019). Faktor-Faktor yang Mempengaruhi Terjadinya Diabetes Melitus di Puskesmas Harapan Raya Tahun 2018. Scientia Journal, 8(1), 28-39. JOUR.

Kekenusa, J. S., Ratag, B. T., \& Wuwungan, G. (2013). Analisis hubungan antara umur dan riwayat keluarga menderita DM dengan kejadian penyakit DM tipe2 pada pasien rawat jalan di poliklinik penyakit dalam BLU RSUP Prof. RD Kandou Manado. Vol. 0. Universitas. JOUR.

Kementerian Kesehatan, R. I. (2013). Riset kesehatan dasar (Riskesdas) 2013. Jakarta: Badan Penelitian Dan Pengembangan Kesehatan. JOUR.

Kistianita, A. N., Yunus, M., \& Gayatri, R. W. (2018). Analisis faktor risiko diabetes mellitus tipe 2 pada usia produktif dengan pendekatan WHO stepwise step 1 (core/inti) di Puskesmas Kendalkerep Kota Malang. Preventia: The Indonesian Journal of Public Health, 3(1), 85-108. JOUR.

Kurniawaty, E., \& Yanita, B. (2016). Faktor-faktor yang berhubungan dengan kejadian Diabetes Melitus tipe II. Jurnal Majority, 5(2), 27-31. JOUR. Kusnadi, G., Murbawani, E. A., \& Fitranti, D. Y. (2017). Faktor risiko diabetes melitus pada petani dan buruh. DISS, Diponegoro University.

Lathifah, N. L. (2017). Hubungan durasi penyakit dan kadar gula darah dengan keluhan subyektif penderita diabetes melitus. Jurnal Berkala Epidemiologi, 5(2), 231-239. JOUR.

Megawati, F., Agustini, N. P. D., \& Krismayanti, N. L. P. D. (2020). STUDI RETROSPEKTIF TERAPI ANTIDIABETIK PADA PENDERITA DIABETES MELITUS RAWAT INAP DI RUMAH SAKIT UMUM ARI CANTI PERIODE 2018. Jurnal Ilmiah Medicamento, 6(1), 28-32. JOUR.

Ogurtsova, K., da Rocha Fernandes, J. D., Huang, Y., Linnenkamp, U., Guariguata, L., Cho, N. H., ... Makaroff, L. E. (2017). IDF Diabetes Atlas: Global estimates for the prevalence of diabetes for 2015 and 2040. Diabetes Research and Clinical Practice, 128, 40-50. JOUR.

Palimbunga, T. M., Ratag, B. T., \& Kaunang, W. P. J. (2017). FaktorFaktor Yang Berhubungan dengan Kejadian Diabetes Melitus Tipe 2 di RSU Gmim Pancaran Kasih Manado. Media Kesehatan, 9(3). JOUR.

Prabowo, A., \& Hastuti, W. (2015). Hubungan pendidikan dan dukungan keluarga dengan kepatuhan diit pada penderita diabetes mellitus di wilayah Puskesmas Plosorejo Giribangun Matesih Kabupaten Karanganyar. Jurnal Keperawatan GSH, 4(2). JOUR. Purnama, A., \& Sari, N. (2019). Aktivitas Fisik dan Hubungannya dengan Kejadian Diabetes Mellitus. Window of Health: Jurnal Kesehatan, 368-381. JOUR.

Ramadhan, M. (2017). Faktor yang 
ISSN Cetak 2303-1433

ISSN Online: 2579-7301

Berhubungan dengan Kejadian

Diabetes Mellitus di RSUP DR

WAHIDIN SUDIROHUSODO DAN

RS Universits Hasanuddin Makassar

Tahun 2017. Makassar: Fakultas

Kesehatan Masyarakat Universitas

Hasanuddin. JOUR.

Rini, W. N. E., \& Halim, R. (2018).

Determinan Diabetes Melitus Tipe 2 Di

Kelurahan Talang Bakung Kota Jambi.

Jurnal Kesmas Jambi, 2(1), 50-58. JOUR.

Rovy, N. W. (2018). HUBUNGAN

BEBERAPA FAKTOR YANG

DAPAT DIMODIFIKASI DENGAN

KEJADIAN DIABETES MELITUS

TIPE 2 PADA CALON JEMAAH

HAJI DI KABUPATEN MAGETAN.

DISS, STIKES BHAKTI HUSADA

MULIA.

SAFITRI, Y., \& NURHAYATI, I. K. A. (2019). PENGARUH PEMBERIAN

SARI PATI BENGKUANG

(Pachyrhizus Erosus) TERHADAP

KADAR GLUKOSA DARAH PADA

PENDERITA DIABETES MELLITUS

TIPE II USIA 40-50 TAHUN DI

KELURAHAN BANGKINANG

WILAYAH KERJA PUSKESMAS

BANGKINANG KOTA TAHUN

2018. Jurnal Ners, 3(1), 69-81. JOUR.

Saputri, E. G., Setiani, O., \& Dewanti, N. A.

Y. (2018). Hubungan Riwayat Pajanan

Pestisida Dengan Kejadian Diabetes

Melitus Tipe 2 Pada Petani Penyemprot

Di Kecamatan Ngablak Kabupaten

Magelang. Jurnal Kesehatan

Masyarakat (e-Journal), 6(1), 645-653.

JOUR.

Sudargo, T., Freitag, H., Kusmayanti, N. A., \& Rosiyani, F. (2018). Pola makan dan obesitas. BOOK, UGM press.

Sukmaningsih, W. R., Heru SubarisKasjono, S. K. M., \& Werdani, K. E. (2016).

Faktor Risiko Kejadian Diabetes

Mellitus Tipe II di Wilayah Kerja

Puskesmas Purwodiningratan

Surakarta. DISS, Universitas

Muhammadiyah Surakarta.

Tandra, H. (2017). Segala sesuatu yang

harus anda ketahui tentang diabetes.

BOOK, Gramedia Pustaka Utama.
Trisnawati, S. K., \& Setyorogo, S. (2013).

Faktor risiko Kejadian diabetes melitus tipe II di puskesmas kecamatan cengkareng Jakarta Barat Tahun 2012. Jurnal Ilmiah Kesehatan, 5(1), 6-11. JOUR.

Ujani, S. (2016). Hubungan antara usia dan jenis kelamin dengan kadar kolesterol penderita obesitas rsud abdul moeloek provinsi lampung. Jurnal Kesehatan, 6(1). JOUR.

VALOKA, A. D. W. I., \& Reinaldi, H. (2017). Dampak Negatif Makanan Cepat Saji Terhadap Kesehatan Tubuh Manusia Di Kota Bandung Melalui Still Life Photography. Nama: Angga Dwi Valoka NIM: 126020011. DISS, Fotografi \& Film.

Wicaksono, A. P. (2015). Pengaruh pemberian ekstrak jahe merah (zingiber officinale) terhadap kadar glukosa darah puasa dan postprandial pada tikus diabetes. Jurnal Majority, 4(7), 97102. JOUR.

Yosmar, R., Almasdy, D., \& Rahma, F. (2018). Survei Risiko Penyakit Diabetes Melitus Terhadap Masyarakat Kota Padang. Jurnal Sains Farmasi \& Klinis, 5(2), 134-141. JOUR. 